\title{
CLASSROOM MANAGEMENT OF READING INSTRUCTION AT SMP NEGERI 16 BANDA ACEH
}

\author{
Sariakin \\ STKIP Bina Bangsa Getsampena Banda Aceh \\ Email: sariakin70@gmail.com
}

\begin{abstract}
The aims of this research are (1) to find out how the teachers prepares classroom management of reading instruction at the second year students of SMP Negeri 16 Banda Aceh, (2) to find out how classroom management of reading instruction is applied by teachers of SMP Negeri 16 Banda Aceh, and (3) to find out the effect of classroom management of reading instruction on the students' ability of SMP Negeri 16 Banda Aceh in mastering reading comprehension. This study belongs to qualitative research because only describes the situation and condition of applying classroom management in reading instruction at the school. The subjects this study is two English teachers who teach at the school. The instruments that are used to collect data are observation, interview, and documentation. The data gotten is analyzed by narration procedure and discussed. The result of research shows that the teachers prepare classroom management of reading instruction by preparing lesson plan, materials, and conducive environment for instruction process. Furthermore, the teachers usually apply cooperative learning "The Students Team Achievement Divisions (STAD)" technique in applying classroom management in reading instruction. In addition, using various methods or techniques aim to make the students not bored. The classroom management of reading instruction that the teachers apply is in effective category because it has a good impact on the eighth grade students' ability in mastering reading comprehension. It is proved the students' reading ability is in good category (77.31).
\end{abstract}

Key Words: Classroom Management, Reading Instruction

\section{Introduction}

Reading is one of the most important aspects in teaching English. It is because reading can help students in comprehending English reading text, and can get information from what they have read and comprehend most of the books written English. According to Grellet (2001), reading is one of man's greatest achievements where he has ability to put down printed or written word in her feeling and idea. In fact, this ability cannot be achieved without any effort. Students and teachers must show their enthusiasm and eagerness in studying reading comprehension.

Management is the act or skill of dealing with people or situations in a successful way. Classroom management is time management or the way in which someone organize how he or she spend his or her time (Leaser, 2006). To develop fluent readers by providing time during the school day for students to select a book and read 
quietly. Nearly every classroom provides some time during the instructional day for this independent silent reading.

The previous research showed that students need at least 90 minutes of uninterrupted reading instruction per day in order for suffici ${ }^{\mathrm{e}} \mathrm{nt}$ students reading development, and this instruction must be dense and differentiated across the classroom (Homby, 2003).

When students are reading longer tests, often teachers sample oral reading from several or all students and then move away from the table to confer with individuals or even begin another group. If teacher introduce the text and then ask students to go to their desks to read, teacher risk interruption of concentration. Letting them continue to read at the table and help them focus the most of teacher's instruction. Students may stay at the table at least as long as 30 minutes, nevertheless teacher's teaching time is distributed among more students (Homby, 2003).

Considering to its concern, students have to improve reading material to support their study in mastering science and technology, seeking a job or continuing their study to the higher level. Because of this crucial role of reading, the writer chooses reading as the main topic of this research and has a great hope to find out the way to manage the classroom in order the students' ability in mastering reading can be increased. Therefore, to know how to manage the classroom well and to help students in mastering reading skill, the researcher conducts a study about classroom management in teaching reading.
Furthermore, this research is conducted at SMP Negeri 16 Banda Aceh because of some factors and on of them is that classroom management applied by teachers of the school in reading instruction is in good category. It is proved that the students' ability of the school in mastering reading comprehension is in a good category or the students' average score in mastering reading comprehension is 72.2 .

\section{Research Method}

a. Research Design

This research is conducted at SMP Negeri 16 Banda Aceh. The design used in this research is descriptive research. The descriptive research used to analyze and find out the description of the classroom management in reading instruction which is applied at the school. Therefore this research belongs to qualitative research because only analyzes and describes the situation and classroom management of teaching learning process of reading at the school.

\section{b. Subject of Research}

The subject of this research is two English teachers who teach at the school and they are as data source of this research. Besides, the subject of this study is all students of the eighth grade. The total number of the second year students is 89 .

\section{c. Source of Data}

The source of data relate to all research problems in this research are the results of classroom observation and responses of the respondents. The classrooms observations' results are related to the classroom management applied by teachers. The responses of the 
respondents deal with the teachers' understanding of classroom management, the evaluation of the students, and on the problems confronting the teachers in implementing classroom management.

\section{d. The Instruments of Collecting Data}

The instruments are used by the researcher in collecting data are observation sheet, interview, and documents.. The data are collected by observing classroom management for teaching and learning process, interviewing the teacher, and analyzing documents.

\section{e. Data Analysis}

In this research, after gathering the data through the observational instruments and interview, the researcher analyzes the data. The data are analyzed by organizing the collected data systematically. The data are grouped and classified based on the research problems. The data are qualitatively analyzed by the researcher to identify, sort extract, and recognize the verbal instructions and then, group them according to the topic. Next, the data gotten are analyzed by narrating procedure and discussing.

\section{Result of Research}

The teachers preparing lessons plan, materials, and conducive environment of instruction in preparing classroom management of reading instruction. Next, the teachers applies learner-centered approach in managing classroom in reading instruction. However, the teachers sometimes apply more than one approach in conducting the teaching and learning activities based on the situation and condition of the students in the classroom.

In the case of teaching and learning, learner-centered activities are often used in the teaching process, two of respondents often presented describing and drawing and information. It is supported by Harjono (2000) that a variety of activities can be used by the English teachers in applying learner-centered approach such as games problem solving, role play, question and answer and etc. In realization of learner-centered activities, two of the teachers always ordered the students to sit in group. In addition, the teachers usually use cooperative learning "The Students Team Achievement Divisions (STAD " technique and group them to be some groups in managing classroom of reading instruction.

After teaching and learning process, the teachers conducte an evaluation to know the success of managing classroom of teaching and learning process and the students' ability or achievement in mastering the subject that had been discussed. In evaluating, the teachers usually evaluate the students by giving a written test individually. Based on the table, the students' average score is in good category because it is 77.31. The score in Teacher Training and Educational Faculty should be 7.7 and it is also in good category.

Based on the students' score, it can be said that the implementation of classroom management for teaching reading skill at school has a good impact to the students' reading ability because the students' average score is in good category (77.31). 


\section{Discussions}

Preparing classroom management is very important because it affects the result of teaching and learning process. Therefore every teacher should prepare classroom well. Before conducting teaching and learning process, the teachers of SMP Negeri 16 prepare classroom management of reading instruction by preparing lesson plan, materials, and classroom. In designing lesson plan, the teachers have syllabus that functions as guidance in preparing and designing the lesson plan. The lesson plan consists of meeting schedule, materials, medium, method or technique which is used in teaching and learning process, and the technique of evaluation.

Furthermore, in applying the instruction of reading skill, the teachers usually use cooperative learning "STAD" technique and group them to be some groups. Every group consists of 4 till 5 students. In this strategy, they are asked to discuss the text given and find the information in the text. Next, the teachers usually ask the students to discuss the text given and ask them to help one other in comprehending the text given. The use of the technique is very useful in increasing the students' success in mastering reading comprehension. It is proven that the students' ability in mastering reading comprehension is good category. In addition, to make the students not bored, the teachers sometimes apply some various techniques or methods. Next, choosing method or technique in teaching reading skill depends on situation and condition and materials that will be taught.

Every teaching and learning process is finished, the teachers conduct an assessment to know the result of the teaching and learning process normally. Therefore, the teachers of SMP Negeri 16 Banda Aceh always give test after teaching learning process for monitoring the result of teaching learning process. The teachers always require the students to find information based on text given individually. To know the success of the result of teaching and learning process, the teacher usually evaluate the students' reading ability through individual evaluation.

Finally, theory of classroom management by Colin and Robert (2011) and Hombay (1999) is still useful to overcome the classroom management especially in reading instruction. The theory is still effective to be used in answering the problems that relates to the management of teaching and learning process.

\section{Conclusions and Suggestions a. Conclusions}

In preparing classroom management, the teachers prepare lesson plan, materials, and conducive environment of reading instruction. The English teachers do not develop the instructional activities based on their lesson plans because they prepare the lesson plans only to be beneficial for fulfilling in the regulating system requirement in case inspectors and school principles step down to look at the lesson plan.

In conducting classroom management of reading instruction, the teachers usually apply 
Jurnal Sosial Humaniora Sigli (JSH)

p ISSN : 2615-3688

$e$ ISSN : 2716-0270

http://journal.unigha.ac.id/index.php/JSH

cooperative learning "STAD" technique. The classroom management of reading skill that the teachers apply is in good category. Because it has a good impact on the students' ability in mastering reading comprehension. It is proved the students' reading ability is in good category (77.31).

\section{b. Suggestions}

The teachers can improve their knowledge about teaching and learning process by attending professional activities such as; inservice training about teaching instruction, seminars, teachers' discussion group (MPGP), and other related activities, because such activities would widen their horizons in term of understanding curriculums, understanding the activities of the teaching and learning process, and understanding teaching method.

Although the students' ability in reading is good category but they should be more motivated to increase their ability in mastering reading comprehension because they have a good potential to increase their ability in treading skill.

\section{References}

Brown, H., D. 2001. Teaching by Principal: An Interactive Approach to Language Pedagogy. New York: Longman Group Limited.

Callahan, J. 2008. Teaching in the Middle and Secondary School. New York: Mc Millan publishing company.
Colin., S. \& Robert., L. Effective Classroom Management. (on line) http/www. Microsoftreaderbook. Com. Accessed on February 1, 2011.

Dechant., E. 2001. Understanding and Teaching Reading: AnI interactive model. Hillsdale: Lawrence Erlbaum.

Grellet. F. 2001. A Practical Guide to Reading Comprehension Exercise. London: Cambridge University Press.

Harjono, S. 2000. Model

Pembelajaran Bahasa

Inggris. Bandung: Alfabeta.

Hombay .1999. Instructional Models in Class Design. New York: Longman Group Limited.

Larsen, D. 2000. Technique and Principle in Language Learning Teaching, New York: Oxford University Press.

Leaser. 2006. Instruction and Instructional System. California. Good Year Company.

Moleong, L., J. 2017. Metodologi Penelitian Kualitatif. Bandung: PT. Remaja Rosdakarya Offset

Ophelia, H. 2005. Reading Skills for College Students. New Jersey: Prentice Hall. 